\title{
The Effect of Picture Media on Writing Skills of Exposition Notes in Class VIII Madrasah Tsanawiyah Al Hidayah Depok
}

\author{
Endang Sulistyaniningsih*), \\ Universitas Indraprasta PGRI \\ Fatimah, \\ Universitas Indraprasta PGRI \\ *) Kampus A J1. Nangka No.58C Tanjung Barat (TB Simatupang), Jagakarsa, Jakarta Selatan, 12530, Indonesia; \\ e-mail: esulistyaniningsih@gmail.com
}

\begin{abstract}
The purpose of this study was to determine the effect of image media on Indonesian language subjects especially in exposition essay writing skills on class VIII Madrasah Tsanawiyah Al Hidayah Depok. The research method used to analyze is the pretest method, in the form of an exposition essay test before using image and posttest media, in the form of exposition essay tests after using image media. On the pretest test the average score was 73 and the posttest test obtained an average score of 82. The average scores of the two groups were classified into the categories "Enough" and "Good". In testing the Chikuadrat Test, the values for class X1 and X2 are normally distributed with values X1 $1.383<12.592$, and X2 $3.164<12,592$. In testing the Homogeneity Test obtained a value of $1.06 \leq 4.28$, the data is homogeneously distributed. In testing the Hypothesis Test, the results of $t_{-}$(count) are greater than $t$ table $(5.266>2.035)$. Based on the results of these studies, it can be concluded that there is an effect of using image media on exposition essay writing skills on class VIII students of Madrasah Tsanawiyah Al Hidayah Depok before and after using media images.
\end{abstract}

Keywords: Media Picture, Exposition Essay Writing Skills

Article History: Received: 22/05/2019; Revised: 23/06/2019; Accepted: 01/072019; Published: 31/07/2019. How to Cite

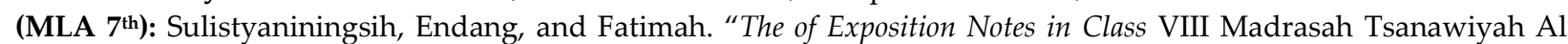
Hidyah Depok." Hortatori Jurnal Pendidikan Bahasa dan Sastra Indonesia 3.01 (2019): 16-21. Print/Online. Copyrights Holder: Endang Sulistyaniningsih, Fatimah. First Publication: Hortatori Jurnal Pendidikan Bahasa dan Sastra Indonesia (2019).

This work is licensed under a Creative Commons Attribution-ShareAlike 4.0 International License.

\section{Pendahuluan}

Media diartikan sebagai channel (saluran) karena pada hakikatnya media membantu memperluas atau memperpanjang kemampuan manusia untuk merasakan, mendengar, dan melihat dalam batas- batas jarak, ruang dan waktu tertentu (Hidayat, 2012: 152). Hal ini berarti media dapat dijadikan sebuah jembatan atau penghubung bagi manusia untuk dapat merasakan, mendengar informasi yang diterima, oleh karena itu media memiliki peran tersendiri untuk menyalurkan sebuah informasi kepada khalayak dengan cara yang berbeda. Gagne (Sadiman, dkk, 2014: 6) menyatakan "Media merupakan berbagai jenis komponen dalam lingkungan siswa yang dapat merangsangnya untuk belajar". Sementara itu, Briggs dalam buku Sadiman (2014: 6) menyatakan, "Media merupakan segala alat fisik yang dapat menyajikan pesan serta merangsang siswa untuk belajar". Media sangat cocok digunakan dalam dunia pendidikan khususnya dalam kegiatan belajar mengajar berlangsung, karena dengan adanya media yang berperan sebagai perantara untuk menyampaiakn informasi dengan cara yang berbeda justru akan membuat peserta didik nyaman dalam kegiatan belajar. 
Pada hakikatnya gambar merupakan pengungkapan secara mental dan visual dari seseorang terhadap apa yang dialaminya dalam bentuk garis (goresan) dan warna (Kusrianto, 2009: 45). Dalam mengungkapan perasaan yang dialami sesorang tidak harus melalui sebuah tulisan atau lambang-lambang aksara saja tetapi dengan sebuah gambar pun kita mampu mengungkapkannya. Oleh Karena itu gambar juga dapat dikategorikan salah satu media yang paling ampuh untuk mengungkapkan perasaan, karena dari sebuah gambar tersimpan sejuta makna di dalamnya. Berdasarkan Kamus Besar Bahasa Indonesia (2013: 409) "Gambar merupakan tiruan barang, orang, binatang, tumbuhan, yang dibuat dengan coretan pinsil dan sebagainya. Jadi gambar adalah sesuatu yang nyata yang ditangkap oleh indera penglihatan dan dituangkan dalam bentuk sebuah gambar". Segala sesuatu yang ditangkap oleh pancaindera dapat dituangkan dalam bentuk apa saja salah satunya sebuah gambar. Maka dari itu gambar juga dapat dijadikan sebagai alat dalam kegiatan pembelajaran, karena pesan yang terdapat dalam sebuah gambar dapat dengan mudah dipahami dan dimengerti oleh peserta didik. Sebuah gambar akan memiliki berbagai makna tergantung bagaimana peserta didik memahami pesan atau infomasi yang terdapat didalamnya. Meskipun demikian, gambar tetap menjadi sebuah media yang dapat menarik minat peserta didik untuk memahami pesan yang terkandung dalam sebuah gambar tersebut. Dari beberapa pemahaman oleh para ahli tersebut di atas, dapat disimpulkan bahwa media gambar adalah alat bantu atau perlengkapan yang efektif dan efisien dalam berkomunikasi antara pendidik dengan peserta didik dalam kegiatan belajar mengajar di kelas. Media gambar adalah media yang paling digemari oleh peserta didik dibandingkan dengan verbal atau teks wacana.

Menulis merupakan bagian dari keterampilan berbahasa yang dilakukan dengan cara menuangkan apa yang dirasakan penulis dalam bentuk tulisan atau lambang-lambang aksara yang tidak mudah, karena tidak semua orang mampu melakukan atau menggemari kegiatan menulis. Menulis merupakan suatu kegiatan untuk menciptakan suatu catatan atau informasi pada suatu media dengan menggunakan aksara, (Alek dan Achmad, 2010: 106). Akhadiah (2016: 41) menyatakan "Menulis merupakan proses bernalar. Untuk menulis mengenai suatu topik kita harus berpikir, dengan menghubung-hubungkan berbagai fakta, membandingkan dan sebagainya." Dalam hal ini menulis sama halnya dengan tes secara subjektif artinya kita menuangkan ide atau gagasan yang kita miliki sesuai dengan apa yang kita lihat dan kita rasakan sesuai dengan fakta. Oleh karena itu, menulis merupakan kegiatan atau kemampuan bahasa yang aktif produktif karena menulis merupakan salah satu dari empat keterampilan berbahasa. Menulis juga bukan sekadar menuangkan ide dan gagasan yang kita miliki saja, terutama dalam menulis topik maka penulis harus berpikir secara matang dan harus disajikan dengan fakta.

Rusyana (Hasani, 2013: 3) menyatakan "Menulis merupakan sebuah karangan dalam susunan bahasa sebagai pengutaraan pikiran, perasaan, penginderaan, khayalan, kehendak, keyakinan, dan pengalaman". Hal ini berarti bahwa menulis merupakan kegiatan yang didasari oleh pengutaraan perasaan, khayalan, keyakinan, dan pengalaman pribadi atau orang lain yang dirangkai susunan bahasanya hingga membentuk sebuah tulisan. Sehingga dapat disimpulkan bahwa menulis bukan hanya memindahkan ide yang kita miliki dalam bentuk tulisan begitu saja. Tetapi harus dituangkan secara logis dan sistematis. Ideide yang muncul tersebut merupakan sebuah pengutaraan dalam bentuk pikiran, perasaan, khayalan, pengalaman dan sebagainya. Menulis adalah kegiatan yang dilakukan seseorang untuk menghasilkan tulisan dan segenap rangkaian kegiatan seseorang dalam rangka mengungkapkan gagasan dan menyampaikannya melalui bahasa tulis kepada orang lain agar mudah dipahami (Nurudin, 2010: 4). Tujuan utama dalam menulis adalah untuk menghasilkan sebuah tulisan, hasil tulisan tersebut diperoleh dari kegiatan menulis dengan cara mengungkapkan gagasan yang disampaikan melalui bahasa tulis. Oleh karena itu hasil tulisan yang dapat dibaca dihasilkan dari kegiatan menulis yang dilakukan seseorang dalam menuangkan ide atau gagasan mereka dalam bentuk tulisan yang memuat sebuah informasi didalamnya.

Alek dan Achmad (2010: 107) menyatakan bahwa "Keterampilan menulis merupakan latihan untuk mengembangkan gagasan menjadi kalimat topik, melengkapi paragraf dengan kalimat topik, mengembangkan kalimat topik menjadi kalimat paragraf, menulis paragraf secara utuh, mengembangkan paragraf menjadi karangan yang lebih luas, kemudian menulis karangan secara utuh". Akhadiah (2016: 2) menyatakan "keterampilan menulis merupakan kemampuan kompleks, yang menuntut sejumlah pengetahuan dan keterampilan". Keterampilan menulis bukan hanya terampil dalam menuangkan ide atau gagasan yang kita miliki saja ke dalam sebuah tulisan, tetapi keterampilan menulis harus mencakup pengetahuan di dalamnya, karena dari pengetahuan yang luas akan menjadi salah satu acuan agar keterampilan menulis dapat lebih kompleks. Keterampilan menulis dan media merupakan dua hal yang sangat berbeda, akan tetapi keterkaitan antar keduanya tidak dapat terelakkan. Keterampilan menulis merupakan kegiatan berkomunikasi yang dilakukan dalam bentuk tulisan, sedangkan media merupakan 
sarana untuk menyampaikan sebuah informasi guna mencapai tujuan. Keterampilan menulis dengan menggunakan media dapat menarik perhatian peserta didik dan mampu menghilangkan kejenuhan dalam kegiatan pembelajaran. Hanya saja pendidik kurang memanfaatkan media gambar dalam pembelajaran menulis. Media gambar memiliki daya tarik tersendiri sehingga siswa tidak merasa bosan atau jenuh dalam melakukan kegiatan tulis menulis khususnya kegiatan menulis karangan eksposisi.

Mengingat pentingnya keterampilan menulis, khususnya dalam kegiatan menulis karangan eksposisi, pendidik perlu melatih peserta didik agar mampu menuangkan ide atau gagasan mereka secara singkat, akurat, dan tersusun sistematis. Banyak faktor penyebab motivasi peserta didik kurang/rendah dalam melakukan kegiatan menulis, oleh karena itu pendidik harus memiliki peran yang sangat penting untuk memotivasi siswanya dalam kegiatan menulis. Metode pembelajaran yang monoton dan tidak adanya pemanfaatan media pembelajaran membuat siswa merasa bosan dan kurang tertarik saat mengikuti pembelajaran. Sadiman (2010: 89) berpendapat bahwa di dalam kegiatan belajar mengajar peranan motivasi baik intrinsik maupun ekstrinsik sangat diperlukan.

Karangan eksposisi adalah suatu tulisan yang bertujuan memberikan suatu informasi kepada pembaca, menjelaskan tentang sesuatu, biasanya berisi pengertian dan pengetahuan yang disampaikan dengan singkat, akurat dan jelas (Nurnaningsih, dkk, 2012: 152), Hasani sependapat (2013: 37) mengatakan bahwa "Karangan eksposisi ialah tulisan yang berusaha menerangkan, menjelaskan dan menguraikan masalah, persoalan, atau ide yang dapat memperluas pandangan membaca." Dalam hal ini menyatakan bahwa karangan eksposisi adalah sebuah karangan yang berusaha memberikan sebuah informasi yang disampaikan kepada pembaca dengan singkat, akurat dan jelas. Oleh karena itu karangan eksposisi selain untuk memberikan informasi, karangan eksposisi juga menyampaikan pengetahuan dengan cara yang singkat, akurat, dan jelas. Sehingga pembaca dapat memperoleh informasi yang luas dan memudahkan pembaca untuk memahami sebuah wacana.

\section{Metode}

Metode yang digunakan dalam penelitian ini adalah metode eksperimen. Menurut Sugiyono (2016: 72) "Metode penelitian eksperimen dapat diartikan sebagai metode penelitian yang digunakan untuk mencari pengaruh perlakuan tertentu terhadap yang lain dalam kondisi yang terkendali." Prosedur penelitian dilakukan untuk mengungkapkan hubungan antar variabel satu dengan variabel lainnya dengan cara, siswa diminta untuk mengarang sebelum dan sesudah menggunakan media gambar sesuai tema yang sudah ditentukan oleh peneliti, yaitu Kenakalan Remaja. Peneliti menguji pengaruh antara dua penilaian, yaitu pretest adalah tes karangan eksposisi sebelum menggunakan media gambar dan posttest adalah tes karangan eksposisi sesudah menggunakan media gambar. Peneliti mempergunakan dua kelas untuk mengetahui ada atau tidak pengaruh penggunaan media gambar terhadap keterampilan menulis karangan eksposisi pada siswa kelas VIII Madrasah Tsanawiyah AL Hidayah Depok.

Populasi dalam penelitian ini adalah siswa kelas VIII pada Madrasah Tsanawiyah Al Hidayah Depok yang berjumlah 353 siswa tahun ajaran 2017/2018. Sampel yang digunakan dari populasi 352 diperoleh jumlah 35 siswa dari kelas VIII-A dan VIII-B Madrasah Tsanawiyah Al Hidayah Depok. Pengambilan sampel ini dilakukan pada dua kelas yaitu kelas A sebagai sampel A diperoleh berdasarkan dengan nomor urut ganjil, sedangkan kelas B sebagai sampel B diperoleh berdasarkan nomor urut genap.

Hipotesis dilakukan dengan cara membandingkan data sebelum dengan data sesudah perlakuan dari satu kelompok sampel atau membandingkan data antar waktu dari satu kelompok sampel, maka dilakukan pengujian hipotesis komparasi dengan Uji-t yang membandingkan nilai $t_{\text {hitung }}$ dengan $t_{\text {tabel }}$ sebagai berikut:

1. $t_{\text {hitung }}<t_{\text {tabel }}$, maka terima Ho yang berarti "Tidak ada pengaruh yang signifikan dalam membuat karangan eksposisi menggunakan media gambar pada siswa kelas VIII Madrasah Tsanawiyah Al Hidayah Depok.

2. $t_{\text {hitung }}>t_{\text {tabel }}$, maka tolak Ho yang berarti "Ada pengaruh yang signifikan dalam membuat karangan eksposisi menggunakan media gambar pada siswa kelas VIII Madrasah Tsanawiyah Al Hidayah Depok. 


\section{Hasil dan Diskusi}

\section{Keterampilan menulis karangan eksposisi sebelum menggunakan media gambar}

Data dalam penelitian ini diperoleh dengan cara meminta siswa untuk mengarang tanpa menggunakan media gambar. Keterampilan menulis karangan eksposisi sebelum menggunakan media gambar diberikan symbol $\mathrm{X}_{1}$ dengan jumlah 35 siswa. Simbol $\mathrm{X}_{1}$ adalah nilai yang diperoleh melalui tes menulis, dapat dikatakan bahwa nilai rata-rata dari variabel keterampilan menulis karangan eksposisi siswa sebelum menggunakan media gambar $\left(X_{1}\right)$ diperoleh angka 73. Angka tersebut setelah dikonsultasikan dengan skala penilaian berada pada nilai rentang antara 56-74. Nilai rentang tersebut berkategori cukup, artinya keterampilan menulis karangan eksposisi sebelum menggunakan media gambar siswa kelas VIII Madrasah Tsanawiyah Al Hidayah Depok berkategori cukup.

Langkah selanjutnya mengunakan Uji Normalitas data yang dilakukan dengan melakukan pengujian terhadap normal tidaknya data yang akan dianalisis. Penelitian dilakukan untuk menguji dua variabel yang berbeda. Uji normalitas ini dilakukan dengan menggunakan uji Chi Kuadrat, selanjutnya adalah menentukan nilai tepi kelas atas dan bawah setiap interval kelas kemudian mengkonversi setiap nilai tepi kelas tersebut menjadi nilai baku dan selanjutnya menentukan nilai $\frac{(f o-f e)^{2}}{f e}$. Membandingkan $X^{2}{ }_{\text {hitung }}$ dengan $X^{2}{ }_{\text {tabel }}$. Dengan membandingkan $X^{2}$ hitung dengan $X^{2}$ tabel untuk $\alpha=0,05$ dengan derajat kebebasan $(\mathrm{dk})=\mathrm{k}-1=7-1=6$, maka dicari pada tabel chi-kuadrat didapat $X^{2}$ tabel $=12,592$.

Kriteria pengujian sebagai berikut:

- Jika $X^{2}{ }_{\text {hitung }}<X^{2}$ tabel, artinya distribusi data normal.

- Jika $X^{2}$ hitung $>X^{2}$ tabel, artinya distribusi data tidak normal.

Ternyata $X_{\text {hitung }}^{2}<X^{2}$ tabel , atau $1,383<12,592$.

Jadi, menulis karangan eksposisi sebelum menggunakan media gambar pada siswa kelas VIII Madrasah Tsanawiyah Al Hidayah Depok, tahun ajaran 2017-2018 berasal dari populasi yang berdistribusi normal.

\section{Keterampilan menulis karangan eksposisi sesudah menggunakan media gambar}

Data dalam penelitian ini diperoleh dengan cara meminta siswa untuk mengarang menggunakan media gambar. Keterampilan menulis karangan eksposisi sesudah menggunakan media gambar diberikan simbol $\mathrm{X}_{2}$ dengan jumlah 35 siswa. Simbol $\mathrm{X}_{2}$ adalah nilai yang diperoleh melalui tes menulis, dapat dikatakan bahwa nilai rata-rata dari variabel keterampilan menulis karangan eksposisi siswa sesudah menggunakan media gambar $\left(\mathrm{X}_{2}\right)$ diperoleh angka 82. Angka tersebut setelah dikonsultasikan dengan skala penilaian berada pada nilai rentang antara 76-85. Nilai rentang tersebut berkategori baik, artinya keterampilan menulis karangan eksposisi sesudah menggunakan media gambar siswa kelas VIII Madrasah Tsanawiyah Al Hidayah Depok berkategori baik.

Langkah selanjutnya mengunakan Uji Normalitas data, Uji normalitas dilakukan dengan menggunakan uji Chi Kuadrat setelah membantu tabel distribusi frekuensi, langkah selanjutnya adalah menentukan nilai tepi kelas atas dan bawah setiap interval kelas kemudian mengonversi setiap nilai tepi kelas tersebut menjadi nilai baku dan selanjutnya menentukan nilai $\frac{(f o-f e)^{2}}{f e}$, Membandingkan $X_{\text {hitung }}^{2}$ dengan $X^{2}$ tabel. Dengan membandingkan $X^{2}{ }_{\text {hitung }}$ dengan $X^{2}$ tabel untuk $\alpha=0,05$ dengan derajat kebebasan $(\mathrm{dk})=\mathrm{k}-1=7-1=6$, maka dicari pada tabel chi-kuadrat didapat $X^{2}$ tabel $=$ 12,592 .

Kriteria pengujian sebagai berikut:

- Jika $x^{2}$ hitung $<x^{2}$ tabel, $\mathrm{H}_{0}$ diterima (data sampel berasal dari populasi berdistribusi normal).

- Jika $x^{2}$ hitung $>x^{2}$ tabel, $\mathrm{H}_{0}$ ditolak (data sampel berasal dari populasi berdistribusi tidak normal). Ternyata $X_{\text {hitung }}^{2}<X_{\text {tabel }}^{2}$, atau 3,164 $<12,592$.

Jadi, menulis karangan eksposisi sesudah menggunakan media gambar pada siswa kelas VIII Madrasah Tsanawiyah Al Hidayah Depok, dari populasi yang berdistribusi normal. 
Setelah uji normalitas memberi indikasi data hasil penelitian berdistribusi normal, maka dilakukan uji homogenitas dengan metode uji Fisher/Uji F (varians terbesar dibanding varians terkecil). a. Mencari nilai varians terbesar dan varians terkecil, yaitu dengan rumus:

$$
\begin{aligned}
F_{\text {hitung }}=\frac{\text { varians terbesar }}{\text { varians terkecil }} & =\frac{68,82}{64,70} \\
& =1,06
\end{aligned}
$$

b. Membandingkan $F_{\text {hitung }}$ dengan $F_{\text {tabel }}$

$\mathrm{dk}$ pembilang $=\mathrm{n}-1=7-1=6$ untuk (varians terbesar)

$\mathrm{dk}$ penyebut $=\mathrm{n}-1=7-1=6$ untuk (varians terkecil)

Taraf signifikan $(\alpha)=0,05$, maka dicari pada Tabel $\mathrm{F}$ dapat $F_{\text {tabel }}=4,28$.

Kriteria pengujian sebagai berikut:

- Jika $F_{\text {hitung }}<F_{\text {tabel }}$, maka $\mathrm{H}_{0}$ diterima (Homogen).

- Jika $F>F_{\text {tabel }}$, maka $\mathrm{H}_{0}$ ditolak (Tidak Homogen).

Ternyata $F_{\text {hitung }}<F_{\text {tabel }}$, atau $1,06 \leq 4,28$.

Jadi, varians menulis karangan eksposisi sebelum dan sesudah menggunakan media gambar pada siswa kelas VIII Madrasah Tsanawiyah Al Hidayah Depok, tahun ajaran 2017/2018 adalah homogen.

\section{Simpulan}

Setelah dilakukan tahapan demi tahapan dalam penelitian ini, maka peneliti menyimpulkan bahwa keterampilan menulis karangan eksposisi pada siswa kelas VIII Madrasah Tsanawiyah Al Hidayah Depok pada tahun ajaran 2017/2018 adalah sebagai berikut :

1. Penggunaan media gambar terhadap keterampilan menulis karangan eksposisi pada siswa kelas VIII Madrasah Tsanawiyah Al Hidayah Depok pada tes pretest memperoleh nilai rata-rata 73 dan tes posttest memperoleh nilai rata-rata 82. Nilai rata-rata dari kedua kelompok tersebut diklasifikasikan ke dalam kategori "Cukup" dan "Baik".

2. Pada pengujian Uji Chikuadrat diperoleh nilai pada kelas $X_{1}$ dan $X_{2}$ masing-masing berdistribusi normal dengan nilai $\mathrm{X}_{1} 1,383<12,592$, dan $\mathrm{X}_{2} 3,164<12,592$.

3. Pada pengujian Uji Homogenitas diperoleh nilai $1,06 \leq 4,28$, artinya dari pembelajaran menulis karangan eksposisi siswa VIII sebelum dan sesudah menggunakan media gambar memiliki varians yang berdistribusi homogen.

4. Pada Uji Hipotesis diperoleh nilai 5,266 > 2,035, kenyataan bahwa $t_{\text {tabel }}(2,035)$ lebih kecil dari $t_{\text {hitung }}(5,266)$ itu menunjukan bahwa $(\mathrm{Ho})$ ditolak dan $\left(\mathrm{H}_{1}\right)$ diterima. Ho artinya tidak terdapat pengaruh yang signifikan dalam membuat karangan eksposisi menggunakan media gambar. $\mathrm{H}_{1}$ artinya terdapat pengaruh yang signifikan dalam membuat karangan eksposisi menggunakan media gambar. Hal ini dapat disimpulkan bahwa pembelajaran menulis karangan eksposisi siswa kelas VIII sebelum dan sesudah menggunakan media gambar memiliki pengaruh yang signifikan.

\section{Ucapan Terima Kasih}

Penulis mengucapkan banyak terima kasih untuk Madrasah Tsanawiyah Al Hidayah Depok yang telah mengizinkan penulis dalam melakukan penelitan, khususnya Kepala Sekolah Madrasah Tsanawiyah Al Hidayah Depok dan dewan guru, semoga penelitian yang kami lakukan dapat memberikan manfaat rujukan dalam ilmu pengetahuan 


\section{Daftar Rujukan}

Akhadiah, Sabarti, Maidar G. Arsjad, and Sakura H. Ridwan. Pembinaan kemampuan menulis bahasa Indonesia. Erlangga, 2016. Print.

Alek, Achmad, and H. Achmad HP. Bahasa Indonesia untuk perguruan tinggi. Prenada Media, 2010. Print. Departemen Pendidikan Nasional. "Kamus Besar Bahasa Indonesia Edisi Keempat." Jakarta: PT Gramedia Pustaka Utama. 2008. Print.

Hasani, Aceng. Ihwal Menulis. Serang: Untirta Press, 2013. Print.

Hidayat, Syarif. Profesi Kependidikan. Jakarta: PT Pustaka Mandiri, 2012. Print.

Kusrianto, Adi. Pengantar Desain Komunikasi Visual. Yogyakarta: CV Andi Offset, 2007. Print.

Nurnaningsih, dkk. Panduan Kreatif Bahasa Indonesia Tingkat Madya. Jakarta.Inti Prima Promosindo, 2012. Print.

Nurudin. Dasar-Dasar Penulisan. Malang. UMM Press, 2010. Print.

Sadiman, Arif S. Media Pendidikan: Pengertian, Pengembangan dan Pemanfaatannya. Jakarta: PT RajaGrafindo Persada, 2014. Print.

Sugiyono. Metode Penelitian Kuantitatif, Kualitatif, dan R\&D. Bandung: Alfabeta, 2016.

Tarigan, Henry Guntur. Menulis. Bandung: Angkasa, 2008. Print. 